\title{
Jubileusz 65 lat działalności pływalni w Pałacu Młodzieży w Warszawie
}

\author{
Bartłomiej Krynicki, \\ Anna Pawlikowska-Piechotka
}

\section{STRESZCZENIE}

Pałac Młodzieży w Warszawie został oddany do użytku 65 lat temu, w kwietniu 1955 r., jako część gmachu Pałacu Kultury i Nauki, wzniesionego w stylu socrealizmu. Był wówczas niezwykłą atrakcją, oferując dzieciom nieosiagalne gdzie indziej możliwości rozwoju pasji i zainteresowań. Na przykład, kryta pływalnia w Pałacu Młodzieży była i jest nadal jedyną pływalnią w województwie mazowieckim, na której jest możliwe uprawianie skoków do wody. Jest to jednocześnie jedna z kilku pływalni w Polsce, na której można uprawiać tę dyscyplinę w pełnym zakresie konkurencji przez cały rok.

W 2007 r. wpisano Pałac Kultury i Nauki wraz z otoczeniem (Plac Defilad) do rejestru zabytków. Prace modernizacyjne, które miały miejsce w Pałacu Młodzieży, w tym na pływalni PM-PKiN, musiały uwzględnić bardzo restrykcyjne i szczegółowe rekomendacje programu konserwatorskiego, narzucajacego zachowanie historycznych walorów stylu architektonicznego pływalni.

Oddana w 2016 r. ponownie do użytku po zabiegach renowacyjnych pływalnia w PM-PKiN służy obecnie sekcji pływackiej (zajęcia: piłka wodna, skoki do wody, pływanie, aerobik).

Słowa kluczowe: historia architektury, historia sportu, PKiN Warszawa, pływalnia

\section{Wprowadzenie}

Pałac Młodzieży mieści się w północnym skrzydle Pałacu Kultury i Nauki w Warszawie (segment funkcjonalny: 'Wychowanie Fizyczne i Sport'), zabytkowym obiekcie w stylu socrealizmu powstałym 65 lat temu.

Budowę Pałacu Kultury i Nauki w Warszawie rozpoczęto kilka lat po zakończeniu II wojny światowej, miała miejsce w latach 1953-1956, są też źródła podające datę 1952-1955 [por. źródła: Bogusz 1975; Drozdowski, Sołtan, Zahorski 2017; Sigalin 1986; Zieliński 2012]. Budowa gmachu była oficjalnie nazywana w propagandzie darem narodu radzieckiego dla narodu polskiego, w istocie zatrudnionymi przy budowie byli zarówno Rosjanie jak i Polacy, także inne koszty tej inwestycji - materiały budowlane, transport, utrzymanie rosyjskich pracowników - były ponoszone przez stronę polską.

Pełna, oficjalna nazwa tego obiektu brzmiała do 1956 r., początku 'odwilży' politycznej po śmieci Stalina, Pałac Kultury i Nauki im. Józefa Stalina. Znajduje się w ścisłym centrum 
miasta, jego adres to Plac Defilad 1. Plac Defilad, zgodnie z nazwą, był w czasach PRL przeznaczony do uroczystych marszów i defilad z okazji świąt państwowych, w szczególności 1 Maja i 22 Lipca, a zachowana granitowa trybuna od strony ulicy Marszałkowskiej, ozdobiona sylwetką orła, jest świadectwem tamtych wydarzeń. Na co dzień ogromny plac - ział pustką [Drozdowski, Sołtan, Zahorski 2017] ${ }^{1}$.

Pałac Kultury i Nauki w Warszawie został wzniesiony w stylu realizmu socrealistycznego (socrealizmu), kierunku w sztuce radzieckiej obowiązującego od 1934 r. i narzucanego krajom satelickim, w tym Polsce. Socrealizm był obecny w Polsce od 1949 r. w literaturze, filmie, malarstwie, rzeźbie i architekturze, jako ideowe i propagando-

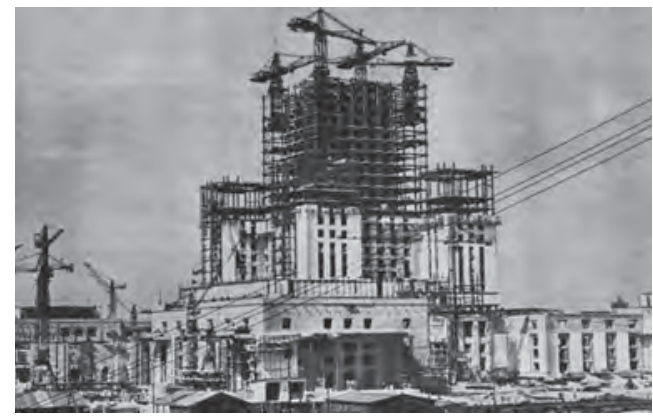

Ryc. 1. Budowa Pałacu Kultury, stan w 1953 r.

Fot. autor nieznany, 1953, Domena Publiczna we narzędzie partii rządzącej (ryc. 1).

Kanony socrealizmu w architekturze zakładały manifestację siły i potęgi idei komunistycznej, co osiagano przez monumentalizm, przeskalowanie, symetrię i obfite stosowanie elementów dekoracyjnych: attyk, kolumnad, pilastrów [Bogusz 1975; Zieliński 2012].

W Polsce styl socrealizmu nawiązywał do historycznych kompozycji, przede wszystkim renesansowych i klasycystycznych, obowiązywał do 1956 r., do schyłku stalinizmu, kiedy został odrzucony z uwagi na przesadny monumentalizm i nieekonomiczne rozwiązania [Bogusz 1975; Sigalin 1986; Zieliński 2012]².

Autorem projektu PKiN był radziecki architekt, Lew Rudniew, który swój projekt wzorował na amerykańskich drapaczach chmur - znał je ze studialnych podróży do Nowego Jorku ${ }^{3}$. W efekcie architektura Pałacu Kultury i Nauki w Warszawie jest mieszanina stylu Art Deco, socrealizmu i elementów polskich dekoracji historycznych, np. attyki skopiowane z polskiego manieryzmu, zgodnie z doktryną 'architektura socrealizmu powinna być socjali-

\footnotetext{
${ }^{1}$ Powierzchnia Placu Defilad wynosi 24 ha, mieści się w kwartale ulic w centrum miasta: Marszałkowskiej, Świętokrzyskiej, Emilii Plater i Alej Jerozolimskich. PKiN i Plac Defilad powstały na siatce istniejacych ulic: Zielnej, Chmielnej, Śliskiej, Złotej. Plac Defilad był miejscem historycznych wydarzeń w 1956 r. - wiecu z udziałem I Sekretarza KC PZPR - Władysława Gomółki, stanowiących symboliczną cezura dla czasów post-stalinowskich w Polsce. W 1987 r. w czasie trzeciej podróży apostolskiej - papież Jan Paweł II odprawił tam mszę święta - ołtarz zbudowano przed wejściem głównym do PKiN. W czasie Mistrzostw Europy w Piłce Nożnej 2012 (UEFA EURO 2012) zorganizowano na Placu Defilad Strefę Kibica [Drozdowski, Sołtan, Zahorski 2017].

${ }^{2}$ Pałac Kultury i Nauki, jest obok zespołu mieszkaniowego MDM, dzielnicy Muranów i dzielnicy 'rządowej' (Krucza, Żurawia, Plac Trzech Krzyży), doskonale zachowanym przykładem architektury okresu socrealizmu w Warszawie. W Polsce do zachowanych zespołów tego stylu zaliczamy Nową Hutę w Krakowie, Centrum Szczecina oraz pojedyncze obiekty, np. Urząd Marszałkowski w Katowicach.

${ }^{3}$ Lew Rudniew (1885-1956), rosyjski i radziecki architekt, był przedstawicielem socrealizmu (realizmu socjalistycznego). Jest autorem projektów gmachu Uniwersytetu Moskiewskiego i Uniwersytetu w Leningradzie, Pałacu Nauki w Rydze i Pałacu Kultury i Nauki w Warszawie [Sigalin 1986; Zieliński 2012].
} 
styczna w treści i narodowa w formie'. Lew Rudniew, który podróżował w celu poszukiwań inspiracji po Polsce, wiele detali elewacji PKiN zaprojektował pod wpływem renesansowych i manierystycznych ratuszy (Zamość, Chełmno) i krakowskich Sukiennic [Bogusz 1975; Drozdowski, Sołtan, Zahorski 2017; Sigalin 1986; Zieliński 2012].

Należy podkreślić, że we wnętrzach gmachu PKiN znajdują się dzieła polskich artystów: rzeźby, malarstwo ścienne, meble, ceramiczne i szklane żyrandole z polskich hut (ryc. 2, 3). Główne wejście do PKiN od strony ulicy Marszałkowskiej jest ozdobione dwiema rzeźbami: Adama Mickiewicza (autor: Stanisław Horno-Popławski) oraz Mikołaja Kopernika (autor: Ludwika Nitschowa). Charakterystyczna, jasna elewacja PKiN, jest efektem obłożenia murów zewnętrznych okładziną w kolorze imitującym piaskowiec, a w istocie będących płytami wykonanymi ze spieków ceramicznych [Bogusz 1975; Sigalin 1986; Zieliński 2012].

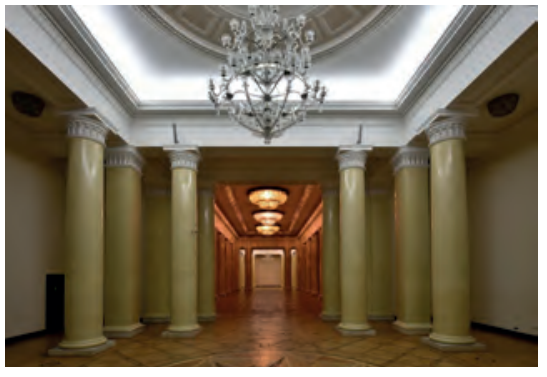

Ryc. 2. Sala im. Stefana Starzyńskiego w PKiN

Fot. A. Grycuk, 2016, CCA-SA 3.0

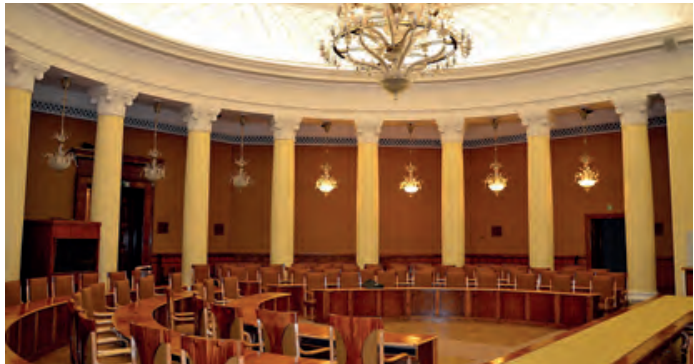

Ryc. 3. Sala Rudniewa w PKiN

Fot. A. Grycuk, 2011, CCA-SA 3.0

Pałac Kultury i Nauki w Warszawie jest monumentalnym gmachem, pomimo otoczenia wznoszonych w XXI w. wieżowców - nadal dominuje przestrzennie w centrum miasta [Crowley 1997; Dorrian 2010]. Jest drugim najwyższym budynkiem w Polsce, ma wysokość całkowitą 237 m (najwyższym będzie wznoszony obecnie Varso Tower w Warszawie o całkowitej wysokości $310 \mathrm{~m}$ ).

Łączna kubatura obiektu wynosi $815000 \mathrm{~m}^{3}$, powierzchnia użytkowa całego gmachu $110000 \mathrm{~m}^{2}$, znajduje się tam blisko 3500 pomieszczeń [Bogusz 1975; Sigalin 1986; Zieliński 2012].

Tak wielka przestrzeń umożliwia pomieszczenie w obiekcie wielorakich funkcji, instytucji kulturalnych, naukowych, administracyjnych i przedsiębiorstw, m.in. teatrów i kin, muzeów, wyższej uczelni, Polskiej Akademii Nauk, Sali Kongresowej (zamkniętej od 2014 r.) (ryc. 4), sal wystawienniczych i targowych, restauracji i pomieszczeń biurowych, w tym Rady m.st.

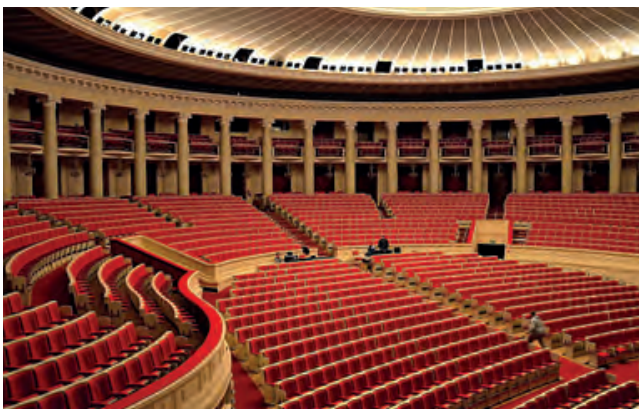

Ryc. 4. Sala Kongresowa w PKiN, wnętrze Fot. A. Grycuk, 2011, CCA-SA 3.0 
Warszawy. Jedną z najbardziej znanych imprez o najdłuższej tradycji są Międzynarodowe Targi Książki, organizowane od 1958 r. [Drozdowski, Sołtan, Zahorski 2017; Zieliński 2009].

Obecnie Pałac Kultury i Nauki jest własnością m.st. Warszawa, zarządza nim spółka Zarząd Pałacu Kultury i Nauki Sp. z o.o.

Pałac Kultury i Nauki został wpisany do rejestru zabytków 2 lutego 2007 r., jako dokument epoki, dobrze zachowane świadectwo stylu socrealistycznego. Uznanie PKiN za obiekt zabytkowy zostało jednak przyjęte przez część społeczeństwa polskiego, w tym przedstawicieli środowiska architektów i historyków sztuki, za wysoce kontrowersyjne posunięcie, ponieważ gmach jest symbolem radzieckiej obecności w Polsce, ciemnej epoki stalinizmu i podporządkowania ZSRR.

Z kolei obrońcy zachowania PKiN (profesorowie: Marek Budzyński, Irena Huml, Stefan Kuryłowicz, Andrzej Tomaszewski, Jarosław Zieliński) wskazywali na wybitne cechy stylowe gmachu, unikatową skalę, wspaniałe detale wnętrz - dzieła wybitnych polskich artystów, m.in. Jana Bogusławskiego i Aliny Szapocznikowej [Huml 2005].

\section{5 lat historii działalności Pałacu Młodzieży w Warszawie}

Pałac Młodzieży jest integralną częścią Pałacu Kultury i Nauki, zajmuje północna część gmachu, wydzielone funkcjonalnie z korpusu gmachu skrzydło z wejściem od ulicy Świętokrzyskiej. W zeszłym roku, ta zasłużona placówka wychowawcza obchodziła jubileusz 65-lecia istnienia. Pałac Młodzieży został zbudowany jako część PKiN z myślą o funkcji placówki wychowania pozaszkolnego. Obiekt rozpoczął działalność w kwietniu 1955 r. (ryc. 5).

Pałac Młodzieży miał w założeniach

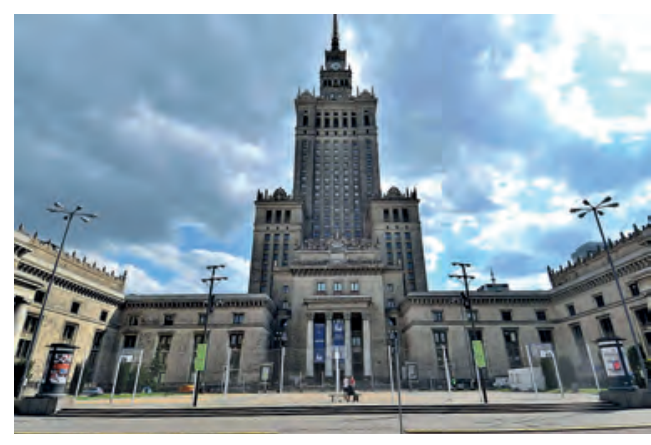

Ryc. 5. Pałac Młodzieży w Warszawie, stan obecny

Fot. A. Grycuk, 2014, CCA-3.0 ideowych być placówką modelowa, wzorem dla innych, mniejszych, mających powstać w innych dzielnicach miasta. Bowiem w założeniach teoretycznych planu 6-letniego w PRL (1949-1955), zgodnie z wizjami urbanistycznymi rozwoju miasta, każda z dzielnic Warszawy miała mieć swój Dom Kultury z sekcja dziecięca i młodzieżowa, pozwalającą na rozwijanie zainteresowań naukowych, artystycznych, społecznych, sportowych i kulturalnych [Drozdowski, Sołtan, Zahorski 2017; Sigalin 1986].

Do realizacji ambitnych i wzorcowych założeń funkcjonowania Pałacu Młodzieży, konieczna była niezwykle staranna selekcja dzieci, jednymi z podstawowych kryteriów były wyniki w nauce i wzorowe zachowanie, w tym tak zwany 'stopień uspołecznienia'. Z uwagi na niezwykle atrakcyjne sekcje (fotograficzna, modelarska, pływanie, muzyczna, taniec) 
i liczbę chętnych, często wielokrotnie przekraczających liczbę miejsc, nabór do tych sekcji przez kilka dekad był związany z obowiązkowymi egzaminami ${ }^{4}$ [pm.waw. pl 2021] (ryc. 6).

Chętnych do uczestniczenia w zajęciach, w ciagu 65 lat działalności placówki, nigdy nie brakowało. Z uwagi na wielorakie ograniczenia $\mathrm{w}$ zajęciach pozaszkolnych w powojennych latach niedostatku, przynależność do sekcji w Pałacu Młodzieży w tych siermiężnych latach PRL, była marzeniem i elitarnym wyróżnieniem, po-

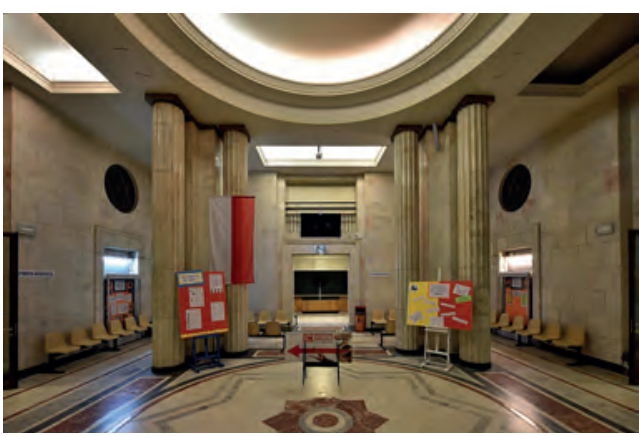

Ryc. 6. Hol przy wejściu głównym do Pałacu Młodzieży w Warszawie

Fot. A. Grycuk, 2016, CCA-SA 3.0 zwalała rozwijać pasje, które w inny sposób nie mogły być realizowane.

Były nimi np. dostęp do możliwości pływania w luksusowych warunkach - wobec nielicznych wówczas w mieście krytych całorocznych pływalni, do bezpłatnych w praktyce a bardzo i trudno dostępnych na rynku niedoborów, kosztownych materiałów modelarskich i fotograficznych [Drozdowski, Sołtan, Zahorski 2017]. Składki miesięczne za przynależność do sekcji były symboliczne, z pewnością nie pokrywały realnych kosztów uczestnictwa w zajęciach. Przykładowo, w latach 1965-1971, wynosiły około 10-15 złotych, chociaż stopniowo je podnoszono.

Część sekcji było bezpłatnych (Klub Filmowy DKF PM, Karta Czytelnika w Bibliotece PM), dzieci mogły też ubiegać się o zwolnienie całkowite lub częściowe z opłat, w wypad$\mathrm{ku}$ trudnej sytuacji materialnej $\mathrm{w}$ rodzinie, zniżki obowiązywały przy zapisach na zajęcia w drugiej sekcji.

W latach 1955-2020 w Pałacu Młodzieży w Warszawie działy m.in. sekcje: fotografii, informatyki, języków obcych, matematyki i informatyki, robotyki, Klub Młodego Odkrywcy, modelarska, muzyczna, plastyczna, pływania, sportu, tańca (choreografii), teatru i DKF. W obrębie sekcji funkcjonowały specjalistyczne pracownie, od jednej do nawet kilkunastu, taki wachlarz możliwości był np. w sekcji plastycznej, sportowej.

Członkowie wszystkich sekcji i podległych im pracowni stanowią grupe kilku tysięcy dzieci i młodzieży w wieku szkolnym, jednocześnie biorących udział w zajęciach, w niektórych latach nawet stanowiąc grupe 5000 osób. W konsekwencji, w ciagu ponad 65 lat funkcjonowania PM, szacuje się, że w latach 1955-2020 w zajęciach organizowanych w Pałacu Młodzieży brało udział blisko 350000 wychowanków [pm.waw.pl 2021].

\footnotetext{
${ }^{4}$ Obecnie także obowiązuje rekrutacja na niektóre zajęcia w Pałacu Młodzieży w Warszawie. Jest oparta o przygotowywane co roku kryteria rekrutacyjne, uwzględniające specyfikę zajęć ( $w$ tym bezpieczeństwo uczestników) - np. obowiązują bardzo szczegółowe wymagania przy zapisach na zajęcia w poszczególnych grupach na basenie PM (tabele 1-4).
} 
Poza zajęciami w okresie szkolnym, w czasie wakacji od 1961 r. organizowane sa obozy w ośrodku Pałacu Młodzieży w Pieczarkach nad jeziorem Dargin (miejscowość pod Węgorzewem, województwo warmińsko-mazurskie). W czasie obozów wakacyjnych 'Lato Mazurskie w Pieczarkach', uczestnicy biorą udział w zajęciach kajakowych, żeglarskich, rowerowych i innych sportowych.

W okresie dwutygodniowych szkolnych ferii zimowych, w okresie PRL niezmiennie co roku trwających w całej Polsce od połowy grudnia do początków stycznia, zawieszano zajęcia w Pałacu Młodzieży i obiekt był otwarty dla odwiedzających. Po wykupieniu biletu, można było zwiedzać cały obiekt z przewodnikiem.

Niezmiennie szczególną atrakcją były pokazy skoków do wody i pływania synchronicznego na krytej pływalni w Pałacu Młodzieży (sama pływalnia była atrakcją turystyczna, podobnie jak Ogród Zimowy), koncerty muzyczne, pokazy gimnastyczne i tańce ludowe w sali gimnastycznej, możliwość odwiedzenia modelarni i pracowni plastycznych oraz długi zjazd między piętrami po słynnej drewnianej 'platformie - tunelu' [pm.waw.pl 2021] .

Obecnie Pałac Młodzieży w Warszawie jest największym w Polsce ośrodkiem oświatowo-wychowawczym w Polsce. Działa od 65 lat mając niezmiennie to samo zadanie: rozbudzać pasje, ambicje i marzenia dzieci i młodzieży, pozwalać rozwijać i pogłębiać zainteresowania.

Podstawą prawną funkcjonowania Pałacu Młodzieży są następujące obowiązujące akty legislacyjne:

1. Ustawa z dnia 14 grudnia 2016 r. Prawo Oświatowe (Dz.U. z dnia 11 stycznia 2017 r. poz. 59).

2. Rozporządzenie Ministra Edukacji Narodowej i Sportu z dnia 7 marca 2005 r. w sprawie ramowych statutów placówek publicznych (Dz.U. z 2005 r., nr 52, poz. 466).

3. Rozporządzenie Ministra Edukacji Narodowej z dnia 15 listopada 2015 r. w sprawie rodzajów i szczegółowych zasad działania placówek publicznych, warunków pobytu dzieci i młodzieży w tych placówkach oraz zasad odpłatności wnoszonej przez rodziców za pobyt dzieci w tych placówkach (Dz.U. z 2015 r. poz. 1872).

Zgodnie ze Statutem Pałacu Młodzieży, zatwierdzonym w 2018 r. przez Radę Pedagogiczna, PM jest pozaszkolna placówką oświatowo-wychowawcza, której organem prowadzącym jest m.st. Warszawa, a organem sprawującym nadzór pedagogiczny - Mazowiecki Kurator Oświaty. Organami wspomagającymi kadrę kierownicza, Dyrekcję i Kolegium Kierownicze Pałacu Młodzieży są Rada Pedagogiczna, Rada Rodziców i Samorząd Uczestników (Rada Młodzieży).

\footnotetext{
${ }^{5}$ Jeden $\mathrm{z}$ autorów artykułu przez wiele lat uczestniczył aktywnie $\mathrm{w}$ takich zimowych 'dniach otwartych' nazywanych 'Gwiazdka w Pałacu Młodzieży' (lata 1965-1971). Były to zajęcia nieobowiązkowe, chętni zgłaszali się wśród uczniów pozostających w mieście. Można było brać udział w pokazowych zajęciach (sekcja teatralna, pływanie synchroniczne, skoki do wody, taniec, gimnastyka artystyczna, pracownia lalkarska i plastyczna), dzieci starsze i młodzież mogli zostać przewodnikiem grup gości lub pracować w służbach porządkowych i informacyjnych. Była to praca, ale wykonywana z dumą i radościa, ponieważ dzięki temu nie tylko prezentowano sukcesy i propagowano działalność Pałacu, ale i zdobywano potrzebne środki na letnie obozy, dofinansowywanie działalności kosztownych sekcji. Panowała znakomita atmosfera. Wielu z odwiedzających, zafascynowanych możliwościami, jakie pracownie oferowały, zapisywało się na zajęcia w Pałacu.
} 
Celem statutowym działalności Pałacu Młodzieży w Warszawie jest realizacja zadań edukacyjnych, wychowawczych, kulturalnych, opiekuńczych, profilaktycznych, prozdrowotnych, rekreacyjnych i sportowych. Cele te są realizowane w szczególności poprzez: stwarzanie warunków do rozwoju zainteresowań młodzieży w różnych dziedzinach (nauka, sztuka, sport), pogłębianie i rozszerzanie wiedzy, wspomaganie funkcji wychowawczych i dydaktycznych szkoły, promowanie zdrowego trybu życia, stwarzanie warunków do podnoszenia sprawności fizycznej, kształtowania umiejętności i wrażliwości twórczej, artystycznej i naukowej, prowadzenie zajęć dla dzieci szczególnie uzdolnionych.

Ponadto do zadań statutowych Pałacu Młodzieży należy organizowanie przeglądów, wystaw, zawodów, turniejów, pokazów i konkursów - o zasięgu warszawskim, ogólnopolskim i międzynarodowym, obejmowanie wychowanków letnim i zimowym wypoczynkiem. Dokumentami pomocniczymi w kształtowaniu programu działalności Pałacu Młodzieży są Program Rozwoju Placówki oraz Wizja i Misja, Model Uczestnika, Program Wychowawczy i Profilaktyki Pałacu Młodzieży, Regulamin Uczestnika [pm.waw.pl 2021].

Statut Pałacu Młodzieży i inne dokumenty odnoszące się do programu działalności określają tryb zajęć uczestników jako możliwy w grupach, zespole, klubie, w stałym tygodniowym rozkładzie dla danej grupy uczestników (poniedziałek - sobota), w wymiarze co najmniej dwóch jednostek dydaktycznych tygodniowo (2 x 45 minut). Uczestnikami zajęć organizowanych w Pałacu Młodzieży mogą być dzieci i młodzież w wieku szkolnym, objęte ustawą Prawo Oświatowe, czyli od 6 do 19 lat.

Rekrutacja na zajęcia odbywa się zgodnie z zasadami określonymi na dany rok szkolny.

W 2020 r. do Pałacu Młodzieży w Warszawie było zapisanych 4000 dziewcząt i chłopców w wieku od 6 do 19 lat, dzieci i młodzież brały udział w zajęciach w kilkunastu sekcjach (kilkudziesięciu pracowniach), pod kierunkiem 89 wychowawców i instruktorów.

Zajęcia sa prowadzone $\mathrm{w}$ następujących segmentach: edukacja czytelnicza, informatyka i nauka, modelarstwo, technika i języki obce, gimnastyka artystyczna i akrobatyka, sport i rekreacja, sztuki piękne, teatr i muzyka, taniec, pływanie i skoki do wody oraz działania środowiskowe [pm.waw.pl 2021].

Obecnie sekcja pływania w Pałacu Młodzieży w Warszawie ma zajęcia następujących pracowni: skoki do wody, pływania synchronicznego, pływania, piłki wodnej oraz aqua aerobiku. Zajęcia w tych sekcjach są podzielone na grupy, w zależności od wieku i stopnia zaawansowania uczestników.

Zajęcia, od 1955 r. do chwili obecnej, mają miejsce na basenie Pałacu Młodzieży (z przerwą na remont kapitalny pływalni w latach 2013-2016) [skokidowody.waw.pl 2021].

\section{Zajęcia sportowe i rekreacyjne na pływalni w Pałacu Młodzieży}

Kryta pływalnia w stylu socrealistycznym, znajdująca się w części północnej budynku PKiN, w Pałacu Młodzieży, należy do specjalnie wyróżnionego w projekcie PKiN segmentu funkcjonalnego 'Wychowanie Fizyczne i Sport'. Należały do niego, poza pływalnia, sala 
gimnastyczna (o wymiarach $35 \mathrm{~m} \times 25 \mathrm{~m}$, pierwotnie z trybunami na 600 miejsc), sale do zajęć tanecznych (z wielkimi lustrami i drążkami do ćwiczeń, piękna posadzką z dębowego parkietu) - wszystkie te części zostały wyposażone we własne, przestronne szatnie i węzły sanitarne.

Pływalnia została zbudowana, tak jak cały gmach, w stylu socrealistycznym, według projektu rosyjskiego architekta Lwa Rudniewa. Niecka basenu miała wymiary $12,5 \mathrm{~m} \times 25 \mathrm{~m}$, trzy trampoliny oraz wieżę do skoków o wysokości poziomów skoków: $10 \mathrm{~m}, 7,5 \mathrm{~m}, 5 \mathrm{~m}$ oraz $3 \mathrm{~m}$ nad lustrem wody. Do budowy basenu i otaczających go trybun użyto marmuru, światło dzienne było górne, wpadało przez przeszklony plafon w suficie ['Sportowiec' $\mathrm{nr} 18$ z kwietnia 1955; Zieliński 2009].

W latach 2013-2016 basen przeszedł gruntowną modernizację, zakończoną w 2016 r. Program prac musiał być starannie wyważonym kompromisem między zadaniami remontowo-budowlanymi a rekomendacjami konserwatora zabytków (ryc. $7,8,9$ ).

Ponieważ PKiN jest wpisany do rejestru zabytków, socrealistyczny oryginalny wystrój wnętrza został zachowany, zmieniono natomiast na nowocześniejsze i bardziej niezawodne systemy uzdatniania wody, wentylacji, termo obiegu, wyremontowano i zmodernizowano pomieszczenia techniczne, szatnie i sanitariaty. Remont obiektu był konieczny ze względu na blisko 60-letnia intensywną i nieprzerwana eksploatację, wymagania bezpieczeństwa w nowych regulacjach prawnych, przestarzałą technologię basenowa w stosunku do wymagań współczesnych [Perkins 2000].

Między innymi zmieniono system przelewu bocznego wody z niecki basenu

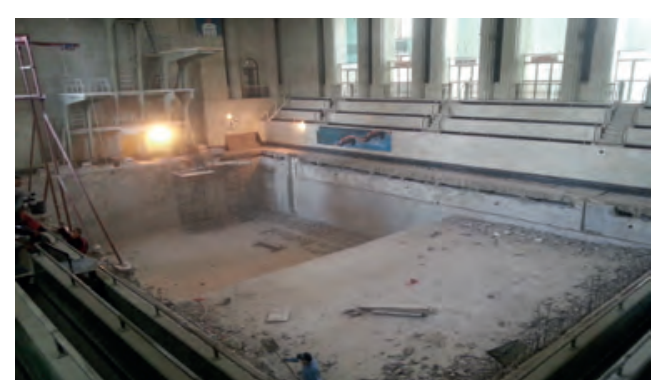

Ryc. 7. Pałac Kultury i Nauki w Warszawie, wnętrze pływalni w Pałacu Młodzieży

(styl socrealizmu), 1955

Stan w czasie remontu kapitalnego w 2014 r.

Fot. B. Krynicki, 2014

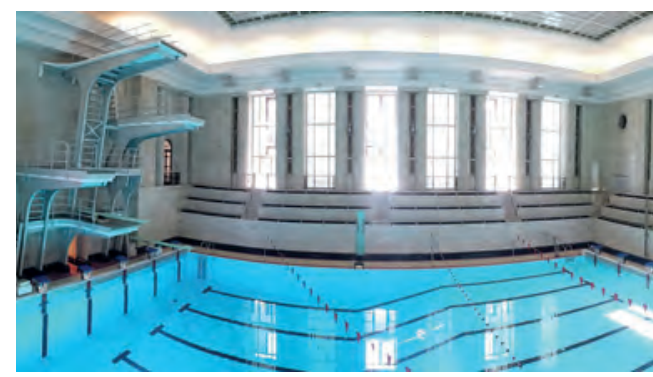

Ryc. 8. Pałac Kultury i Nauki w Warszawie, wnętrze pływalni w Pałacu Młodzieży (styl socrealizmu i Art. Deco), 1955

Stan po remoncie kapitalnym w 2014 r.

Fot. B. Krynicki, 2014

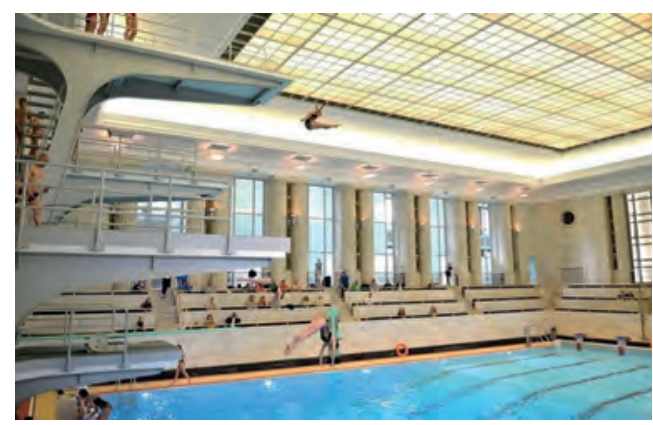

Ryc. 9. Pałac Kultury i Nauki w Warszawie, wnętrze pływalni w Pałacu Młodzieży (styl socrealizmu i Art. Deco), 1955

Stan po remoncie kapitalnym w 2014 r.

Fot. autor nieznany, 2014, archiwum fotografii cyfrowej fotopolska.eu 
na przelew typu Wiesbaden (krawędzie podłużne zbiornika basenu są na poziomie lustra wody, która się przez nie przelewa do kratek zbiorczo-filtrujących), co w konsekwencji spowodowało podniesienie lustra wody $\mathrm{w}$ niecce basenu o $30 \mathrm{~cm}$. W rezultacie tego zabiegu, wieża do skoków wymagała nadbudowy poszczególnych platform o $30 \mathrm{~cm}$, aby spełnić wymagania federacyjne FINA (Federation Internationale de Natation). Ponieważ z jednej strony nie było możliwości konstrukcyjnych podniesienia poziomu stropu, a z drugiej przepisy FINA wymagają zachowania minimalnej odległości poziomu najwyższej platformy od sufitu - nadbudowa nie mogła objać najwyższej platformy i ostatecznie uzyskano wysokości platform wieży do skoków nad lustrem wody odpowiednio: 9,7 m, 7,5 m, 5 m i 3 m.

$\mathrm{Z}$ uwagi na bardzo restrykcyjne wymagania programu konserwatorskiego w celu ochrony zabytkowego stylu obiektu, przy pracach remontowych w szatniach i węzłach sanitarnych zachowano oryginalna, zgodną z historycznym projektem Lwa Rudniewa, kolorystykę płytek ceramicznych - biało-żółta w części damskiej i biało-bordowa w męskiej, a na podłogach elegancką biało-szarą szachownicę z płytek ceramicznych.

Konserwacji poddano oryginalne, w stylu realizmu socjalistycznego z muśnięciem Art Deco - przeszklone plafony sufitowe i towarzyszące im na bordiurze i fasetach dekoracyjne profilowania. Zabiegom modernizacyjnym poddano też stolarkę drzwiową i okienną - wymieniając na nowa, z naturalnego drewna i nawiązującą stylistycznie do oryginalnych wzorów [Wojtysiak 2005].

W celu poprawienia warunków oświetlenia i dostosowania do rekomendacji federacyjnych FINA, zamontowano nowe systemy oświetlenia, m.in. wspomagając reflektory panelami rozpraszającymi dla lepszego doświetlenia lustra wody. W projekcie modernizacji zaproponowano nowe systemy filtracji wody i wentylacji, podnoszace walory użytkowe i zapewniające wyższy standard sanitarny.

Ponadto podniesiono też walory funkcjonalne pływalni, na przykład hol i korytarze zostały oddzielone od hali basenowej szklanymi przegrodami pełnej wysokości pomieszczenia, wykonanymi z paneli ze szkła hartowanego, ujętych w dyskretne aluminiowe ramy.

Warto podkreślić, że w wyniku modernizacji obiektu, wprowadzono innowacyjna technologię pasywna, polegająca na odzyskiwaniu ciepła z obiegu technologicznego (rekuperacja) i wykorzystaniu do podgrzewania wody w basenie. To proekologiczne rozwiązanie pozwoli na oszczędność energii i zmniejszenie jej zużycia ze źródeł nieodnawialnych [nowawarszawa.pl. 2021].

Zabiegom modernizacyjnym poddano w Pałacu Młodzieży cały segment 'Wychowanie fizyczne i sport'. W wyniku tych prac, np. sala sportowa, otoczona z trzech stron drewnianymi trybunami, ma obecnie widownię zredukowaną do 300 miejsc, z uwagi na przepisy bezpieczeństwa. Wymieniono tam również system wentylacji, ogrzewania i oświetlenia oraz posadzkę. Większość treningów grup dzieci i młodzieży uczęszczających na zajęcia na basenie Pałacu Młodzieży (pływanie, skoki do wody) jest połączonych z zajęciami gimnastycznymi na tej sali, uzupełniającymi kierunek głównego treningu.

Obecnie w zajęciach pływalni Pałacu Młodzieży, w czterech różnych sekcjach (piłka wodna, pływanie, aqua aerobik, skoki do wody) uczestniczy kilkaset dziewcząt i chłopców w wieku 6-19 lat, ćwicząc w różnych grupach wiekowych, pod kierunkiem instruktorów i trenerów. Zajęcia 
odbywają się z podziałem na trzy segmenty odpowiadające stopniowi zaawansowania: podstawowy (początkujący), średniozaawansowani, zaawansowani / grupy mistrzowskie (tabele 1-3).

Tabela 1. Zajęcia organizowane na pływalni w Pałacu Młodzieży w Warszawie: piłka wodna (grupy, wiek, wymagania uczestnictwa, efekty)

\begin{tabular}{|c|c|c|c|}
\hline Rodzaj zajęć & $\begin{array}{l}\text { Wiek } \\
\text { (lata) }\end{array}$ & $\begin{array}{c}\text { Wymagania / kryte- } \\
\text { ria kwalifikacji }\end{array}$ & Program zajęć, spodziewane efekty \\
\hline $\begin{array}{l}\text { Grupy } \\
\text { początkowe (15 } \\
\text { osób), F/M }\end{array}$ & $9-12$ & $\begin{array}{l}\text { Dobra umiejętność } \\
\text { pływania, silna budo- } \\
\text { wa ciała, predyspozy- } \\
\text { cje psychofizyczne } \\
\text { Przepłynięcie } 25 \text { m } \\
\text { stylem kraul na czas } \\
\text { oraz stylami grzbie- } \\
\text { towym i klasycznym } \\
\text { (oceniana poprawna } \\
\text { technika) } \\
\text { Ćwiczenia koordy- } \\
\text { nacyjne i siłowe na } \\
\text { lądzie }\end{array}$ & $\begin{array}{l}\text { Nauka i doskonalenie pływania styla- } \\
\text { mi kraulem, grzbietowym, klasycznym } \\
\text { i motylkowym, nauka skoku starto- } \\
\text { wego i nawrotów w poszczególnych } \\
\text { stylach, nauka i doskonalenie techniki } \\
\text { piłki wodnej, udział w zawodach i im- } \\
\text { prezach, udział w obozach letnich, zi- } \\
\text { mowych i zgrupowaniach. } \\
\text { Spodziewane efekty: umocnienie pasji, } \\
\text { zamiłowania do uprawiania sportu, } \\
\text { rozwój ogólny, doskonalenie stylów } \\
\text { pływackich, wiedza o bezpiecznym za- } \\
\text { chowaniu w wodzie. }\end{array}$ \\
\hline $\begin{array}{l}\text { Grupy } \\
\text { zaawansowane, } \\
\text { M }\end{array}$ & $13-18$ & $\begin{array}{l}\text { Bardzo dobra } \\
\text { umiejętność pływa- } \\
\text { nia, silna budowa } \\
\text { ciała, predyspozycje } \\
\text { psychofizyczne do } \\
\text { uprawiania sportu } \\
\text { Przepłynięcie } 50 \text { m } \\
\text { stylem kraul (ocena } \\
\text { techniki i czasu) } \\
\text { Przepłynięcie sty- } \\
\text { lem grzbietowym } \\
\text { i klasycznym (ocena } \\
\text { techniki) } \\
\text { Ćwiczenia koordy- } \\
\text { nacyjne i siłowe na } \\
\text { lądzie }\end{array}$ & $\begin{array}{l}\text { Doskonalenie pływania stylami krau- } \\
\text { lem, grzbietowym, klasycznym i mo- } \\
\text { tylkowym, nauka skoku startowego } \\
\text { i nawrotów w poszczególnych stylach, } \\
\text { nauka i doskonalenie techniki piłki } \\
\text { wodnej, udział w zawodach i impre- } \\
\text { zach, Grand Prix PM w Pływaniu, } \\
\text { Olimpiada Waterpolo PM, Turnieje } \\
\text { Towarzyskie Ogólnopolskie i Między- } \\
\text { narodowe, Warszawska Olimpiada } \\
\text { Młodzieży, udział w obozach letnich, } \\
\text { zimowych i zgrupowaniach. } \\
\text { Spodziewane efekty: umocnienie pasji, } \\
\text { zamiłowania do uprawiania sportu, } \\
\text { rozwój ogólny, ukształtowanie posta- } \\
\text { wy etycznego zawodnika, umiejętność } \\
\text { samokontroli i samooceny. }\end{array}$ \\
\hline
\end{tabular}

Źródło: opracowanie autorów na podstawie materiałów udostępnionych przez Pałac Młodzieży (2021) Objaśnienie: F - dziewczęta, M - chłopcy 
Tabela 2. Zajęcia organizowane na pływalni w Pałacu Młodzieży w Warszawie: pływanie (grupy, wiek, wymagania uczestnictwa, efekty)

\begin{tabular}{|c|c|c|c|}
\hline Rodzaje zajęć & $\begin{array}{l}\text { Wiek } \\
\text { (lata) }\end{array}$ & $\begin{array}{l}\text { Wymagania / kryte- } \\
\text { ria kwalifikacji } \\
\text { do uczestnictwa }\end{array}$ & Program zajęć, spodziewane efekty \\
\hline $\begin{array}{l}\text { Grupy podsta- } \\
\text { wowe (15 osób), } \\
\text { F/M }\end{array}$ & $6-9$ & $\begin{array}{l}\text { Umiejętność pływa- } \\
\text { nia } \\
\text { Przepłynięcie } 25 \text { m } \\
\text { wybranym stylem } \\
\text { (oceniana szybkość) } \\
\text { oraz stylami grzbie- } \\
\text { towym, kraulem, } \\
\text { motylkowym i kla- } \\
\text { sycznym (oceniana } \\
\text { poprawna technika, } \\
\text { pływalność ciała) }\end{array}$ & $\begin{array}{l}\text { Nauka pływania stylami kraulem, } \\
\text { grzbietowym, klasycznym i motylko- } \\
\text { wym, nauka skoku na głowę i na nogi, } \\
\text { nauka nurkowania i prawidłowego } \\
\text { oddychania. } \\
\text { Efekty: wszechstronny rozwój, korek- } \\
\text { ta wad postawy, udział w zawodach } \\
\text { i imprezach, udział w obozach letnich, } \\
\text { zimowych i zgrupowaniach, zdanie } \\
\text { egzaminu na kartę pływacką. }\end{array}$ \\
\hline $\begin{array}{l}\text { Grupy średnio- } \\
\text { zaawansowane } \\
\text { (15 osób), F/M }\end{array}$ & $\begin{array}{c}9-11^{*} \\
\text { oraz } \\
11-13^{*}\end{array}$ & $\begin{array}{l}\text { Bardzo dobra } \\
\text { umiejętność pływa- } \\
\text { nia, silna budowa } \\
\text { ciała, predyspozycje } \\
\text { psychofizyczne do } \\
\text { uprawiania sportu } \\
\text { Przepłynięcie } 25 \text { m } \\
\text { stylem dowolnym } \\
\text { (ocena techniki } \\
\text { i czasu) } \\
\text { Przepłynięcie stylem } \\
\text { grzbietowym, kla- } \\
\text { sycznym i motylko- } \\
\text { wym (ocena techniki) } \\
\text { Skok na nogi lub } \\
\text { głowę }\end{array}$ & $\begin{array}{l}\text { Doskonalenie pływania stylami krau- } \\
\text { lem, grzbietowym, klasycznym i mo- } \\
\text { tylkowym, nauka skoku startowego } \\
\text { i nawrotów w poszczególnych sty- } \\
\text { lach, prawidłowe oddychanie i nur- } \\
\text { kowanie, znajomośc przepisów Mię- } \\
\text { dzynarodowej Federacji Pływackiej } \\
\text { (FINA), zasady bezpiecznego i kultu- } \\
\text { ralnego pływania, udział w zawodach } \\
\text { i imprezach, Grand Prix PM w Pływa- } \\
\text { niu, udział w obozach letnich, zimo- } \\
\text { wych i zgrupowaniach, egzamin na } \\
\text { kartę pływacka. } \\
\text { Efekty: wszechstronny rozwój, korek- } \\
\text { ta wad postawy, udział w zawodach } \\
\text { i imprezach, udział w obozach letnich, } \\
\text { zimowych i zgrupowaniach, zdanie } \\
\text { egzaminu na kartę pływacka. }\end{array}$ \\
\hline
\end{tabular}




\begin{tabular}{|c|c|c|c|}
\hline Rodzaje zajęć & $\begin{array}{l}\text { Wiek } \\
\text { (lata) }\end{array}$ & $\begin{array}{c}\text { Wymagania / kryte- } \\
\text { ria kwalifikacji } \\
\text { do uczestnictwa }\end{array}$ & Program zajęć, spodziewane efekty \\
\hline $\begin{array}{l}\text { Grupa średnio- } \\
\text { zaawansowana } \\
\text { (15 osób), F/M }\end{array}$ & $13-15$ & $\begin{array}{l}\text { Dobra technika } \\
\text { pływania stylem } \\
\text { grzbietowym, stylem } \\
\text { kraul, klasycznym } \\
\text { i motylkowym } \\
\text { Oceniane są technika } \\
\text { i pływalność ciała } \\
\text { Przepłynięcie wy- } \\
\text { branym stylem } 50 \text { m } \\
\text { (oceniane technika } \\
\text { i czas) } \\
\text { Skok na nogi lub } \\
\text { głowę }\end{array}$ & $\begin{array}{l}\text { Doskonalenie pływania stylami krau- } \\
\text { lem, grzbietowym, klasycznym i mo- } \\
\text { tylkowym w stopniu zaawansowa- } \\
\text { nym, doskonalenie skoku startowego } \\
\text { i nawrotów w poszczególnych sty- } \\
\text { lach, prawidłowe oddychanie i nurko- } \\
\text { wanie, wszechstronny rozwój, korekta } \\
\text { wad postawy ciała, uczestnik potrafi } \\
\text { przepłynać } 25 \text { m pod powierzchnia } \\
\text { wody i wyłowić przedmioty z dna } \\
\text { basenu, znajomość przepisów Mię- } \\
\text { dzynarodowej Federacji Pływackiej } \\
\text { (FINA), zasady bezpiecznego i kultu- } \\
\text { ralnego pływania, podstawowe infor- } \\
\text { macje i umiejętności z zakresu ratow- } \\
\text { nictwa wodnego, udział w zawodach } \\
\text { i imprezach, Grand Prix PM w Pływa- } \\
\text { niu, udział w obozach letnich, zimo- } \\
\text { wych i zgrupowaniach, zdanie egza- } \\
\text { minu na kartę pływacką. } \\
\text { Efekty: umocnienie pasji, zamiłowa- } \\
\text { nia do uprawiania sportu, ukształto- } \\
\text { wanie postawy etycznego zawodnika, } \\
\text { umiejętność samokontroli i samooce- } \\
\text { ny. }\end{array}$ \\
\hline
\end{tabular}

Źródło: opracowanie autorów na podstawie materiałów udostępnionych przez Pałac Młodzieży (2021) Objaśnienie: $\left({ }^{*}\right)$ wymienione grupy mają zajęcia oddzielnie, $\mathrm{F}$ - dziewczęta, $\mathrm{M}$ - chłopcy 
Tabela 3. Zajęcia organizowane na pływalni w Pałacu Młodzieży w Warszawie: aqua aerobik (grupy, wiek, wymagania uczestnictwa, efekty)

\begin{tabular}{|c|c|c|c|}
\hline Rodzaj zajęć & $\begin{array}{l}\text { Wiek } \\
\text { (lata) }\end{array}$ & $\begin{array}{c}\text { Wymagania } \\
\text { uczestnictwa / } \\
\text { kryteria kwalifi- } \\
\text { kacji }\end{array}$ & Program zajęć, spodziewane efekty \\
\hline $\begin{array}{l}\text { Grupy } \\
\text { początkowe (15 } \\
\text { osób), F/M }\end{array}$ & $13-15$ & $\begin{array}{l}\text { Dobra umiejęt- } \\
\text { ność pływania, } \\
\text { przepłynięcie } \\
25 \text { m dowolnym } \\
\text { stylem na brzu- } \\
\text { chu i } 25 \text { m na } \\
\text { plecach, skok do } \\
\text { wody na proste } \\
\text { nogi }\end{array}$ & $\begin{array}{l}\text { Doskonalenie pływania stylami kraulem, } \\
\text { grzbietowym, klasycznym, nauka pływa- } \\
\text { nia stylem motylkowym, nauka skoku star- } \\
\text { towego i nawrotów w poszczególnych sty- } \\
\text { lach, doskonalenie technik wykonywania } \\
\text { ćwiczeń z użyciem sprzętu aqua, prowoko- } \\
\text { wanie inspiracji i pobudzanie kreatywno- } \\
\text { ści - samodzielne konstruowanie prostych } \\
\text { układów gimnastycznych w wodzie, ćwi- } \\
\text { czenia relaksacyjne w wodzie. } \\
\text { Efekty: spodziewanymi efektami sa } \\
\text { wzmocnienie siły, wytrzymałości, opano- } \\
\text { wanie umiejętności samokontroli i samo- } \\
\text { oceny, wiedzy o bezpiecznym zachowaniu } \\
\text { nad wodą i w wodzie. }\end{array}$ \\
\hline $\begin{array}{l}\text { Grupy } \\
\text { zaawansowane, } \\
\text { (15 osób) F/M }\end{array}$ & $16-18$ & $\begin{array}{l}\text { Dobra umiejęt- } \\
\text { ność pływania, } \\
\text { przepłynięcie } \\
25 \text { m stylem } \\
\text { kraul (ocena } \\
\text { techniki), } 25 \text { m } \\
\text { stylem grzbie- } \\
\text { towym, skok do } \\
\text { wody na proste } \\
\text { nogi, przepły- } \\
\text { nięcie } 5 \text { m pod } \\
\text { wodą }\end{array}$ & $\begin{array}{l}\text { Doskonalenie pływania stylami kraulem, } \\
\text { grzbietowym, klasycznym, nauka pływa- } \\
\text { nia stylem motylkowym, nauka skoku star- } \\
\text { towego i nawrotów w poszczególnych sty- } \\
\text { lach, doskonalenie technik wykonywania } \\
\text { ćwiczeń z użyciem sprzętu aqua, ćwiczenia } \\
\text { rozciągające, relaksacyjne i odprężające, } \\
\text { prowokowanie inspiracji i pobudzanie kre- } \\
\text { atywności - samodzielne konstruowanie } \\
\text { prostych układów gimnastycznych w wo- } \\
\text { dzie, ćwiczenia relaksacyjne w wodzie. } \\
\text { Efekty: spodziewanymi efektami są } \\
\text { wzmocnienie siły, wytrzymałości, gibkości, } \\
\text { koordynacji ruchowej, opanowanie umie- } \\
\text { jętności samokontroli i samooceny, wiedzy } \\
\text { o bezpiecznym zachowaniu nad wodą. }\end{array}$ \\
\hline
\end{tabular}

Źródło: opracowanie autorów na podstawie materiałów udostępnionych przez Pałac Młodzieży (2021) Objaśnienie: F - dziewczęta, M - chłopcy 
Rekrutacja na zajęcia sportów wodnych na pływalni w Pałacu Młodzieży w Warszawie jest oparta o przygotowywane co roku kryteria rekrutacyjne, uwzględniające specyfikę zajęć, w tym bezpieczeństwo uczestników. Obowiązują bardzo szczegółowe wymagania przy zapisach na zajęcia w poszczególnych grupach. Jest to wyjątkowo konsekwentnie wymagane przy naborze do sekcji skoków do wody, nie tylko z uwagi na bezpieczeństwo uczestników zajęć, ale i na szczególnie wymagane predyspozycje zawodników: od siły mięśni - do harmonii ruchów. Skoki do wody sa uznawane za jedną z najtrudniejszych dyscyplin sportu, będąca na pograniczu akrobatyki, gimnastyki sportowej i umiejętności pływania. Od sportowców jest wymagana odwaga i wysoka sprawność fizyczna, elegancja ruchów i precyzja wykonania ewolucji, pracowitość i wysoka zdolność koncentracji [Wertz 1985].

Uczestnicy zajęć zorganizowanych na pływalni Pałacu Młodzieży biorą udział w imprezach i zawodach pływackich Pałacu Młodzieży (Liga Pływania), Grand Prix w Pływaniu, turniejach piłki wodnej (Splash Ball, Olimpiada Water Polo, Warszawska Olimpiada Młodzieży, Ogólnopolskie Rozgrywki w Pływaniu i wielu innych.

Ponadto jest możliwe wykupienie indywidualnego karnetu na pływanie rekreacyjne w Pałacu Młodzieży (uprawniającego do korzystania z pływalni w określone dni tygodnia i pory dnia przez 45 minut). Chętnie z tej możliwości korzystają nie tylko osoby prywatne, ale i instytucje, chcące dbać o usportowienie swoich pracowników i ofiarujące karnety w ramach bonusu.

Cennik korzystania z obiektu i oferta wstępu na pływalnię są elastyczne, gotowe dostosować się do oczekiwań rynkowego klienta. Szkoły i uczelnie wyższe mają możliwość wynajmowania basenu na zajęcia pływania ze zniżka, a instytucje niepełniące funkcji oświatowych - w pełnej cenie z możliwościa wynajęcia poszczególnych torów, z limitem osób pływających na każdym z nich [pm. waw.pl 2021].

\section{Sekcja skoków do wody Pałacu Młodzieży}

Warto przytoczyć historię sekcji skoków do wody w Pałacu Młodzieży w Warszawie, jednej z pierwszych, najstarszych i nadal nielicznych w Polsce - z uwagi na niedostatek w Polsce pływalni krytych z wieżą do skoków, ponieważ dobrze ilustruje, jakie mogą być znaczące efekty niezwykle konsekwentnie realizowanego, nieprzerwanie od 65 lat, programu szkoleń i treningów.

Tradycja uprawiania skoków do wody w Polsce to okres ostatnich stu lat, majacy swoje początki w II RP (Kraków, Warszawa i Poznań); wcześniej takich możliwości nie było z uwagi na brak odpowiednich obiektów. Do tych tradycji okresu międzywojennego nawiązano powołując sekcję skoków do wody w Pałacu Młodzieży PKiN w Warszawie. Jednym z pomysłodawców sekcji skoków do wody, organizatorem i autorem pierwszych programów szkoleń był Aleksander Rękas, wychowanek trenera Dymitra Bogajewskiego. Dymitr Bogajewski był zasłużonym twórca i pierwszym szefem Zakładu Pływania na AWF Warszawa, jednocześnie trenerem skoków do wody w Klubie AZS-AWF (od 1950) i prekursorem popularyzacji tej dyscypliny sportu w Polsce. 
Po raz pierwszy skoki do wody zaprezentowano z wieży i trampoliny na pływalni w Pałacu Młodzieży w trakcie Światowego Festiwalu Młodzieży i Studentów, podczas uroczystości otwarcia PKiN w Warszawie, w dniu 22 lipca 1955 r.

W tych pokazach brali udział tak znakomici zawodnicy jak: Joaquin Capilla z Meksyku (mistrz olimpijski z Melbourne w 1956), Roman Brenner z ZSRR (medalista Mistrzostw Europy w 1958) oraz Aleksander Rękas, wielokrotny mistrz Polski.

Sekcja skoków do wody na pływalni PM PKiN, do której nabór ogłoszono w 1955 r., przyciagnęła niezwykłą uwagę. Zgłosiło się aż 7000 dzieci, z których po pierwszych testach sprawnościowych, wybrano grupę 850 do zajęć na pływalni. Po roku szkolenia okazało się, że dzieci najmłodsze czynią postępy znacznie wyprzedzające grupy starsze. To dało asumpt do przeredagowania programów szkoleniowych i sformułowanie nowego, innowacyjnego programu, w którym nacisk jest kładziony na rozpoczęcie szkolenia dzieci w wieku 6 lat. We wrześniu 1956 r. rozpoczęto pracę z grupą eksperymentalną (wiek 6-8 lat), zajęcia miały program rozszerzony: gimnastyka i zajęcia w wodzie.

W Letnich Igrzyskach Olimpijskich w Meksyku (1968) trzech wychowanków PM PKiN brało udział w igrzyskach: Elżbieta Wierniuk, Bogusława Marcinkowska i Jakub Puchow.

W 1969 r. powstał w PM PKiN Ośrodek Olimpijski w skokach do wody. Pierwszymi trenerami i autorami programu szkoleń byli Aleksander Rękas, Halina Bartkowiak oraz Józef Włodarczyk. Powołanie Ośrodka, intensywny program dobrze opracowanych szkoleń, przyniosły wymierne efekty: w 1970 r. Jakub Puchow zdobył III miejsce w skokach z wieży, Elżbieta Wierniuk III miejsce w skokach z trampoliny na Uniwersjadzie w Turynie; w Letnich Igrzyskach Olimpijskich w Monachium 1972 r. brali udział wychowankowie PM PKiN (Elżbieta Wierniuk, Regina Krajnow-Synoradzka, Jakub Puchow); na Uniwersjadzie w Moskwie w 1973 r. dwoje zawodników sekcji PM PKiN zajęło IV miejsce w skokach z wieży (Małgorzata Godlewska i Jakub Puchanow).

W latach 1980-2000 wychowankami sekcji skoków PM PKiN byli Krzysztof Miller, wielokrotny mistrz Polski w skokach z trampoliny i wieży, Anna Urbańska-Wierniuk, mistrzyni Polski w skokach z trampoliny, Agnieszka Jackowska, wielokrotna mistrzyni Polski w skokach z wieży i z trampoliny.

W 1994 r. została reaktywowana sekcja skoków humorystycznych (kontynuująca tradycje grupy z lat 60.), bioraca udział w pokazach i imprezach organizowanych zarówno w Pałacu Młodzieży PKiN, jak i przez AWF Warszawa. Do grupy należeli: Włodzimierz i Karol Tanajno, Grzegorz i Robert Krawieccy, Piotr Niemczyński, Bartłomiej Krynicki, Bogdan Krauss, Piotr Kaczmarek, Robert Weglik.

W 2002 r. w Pałacu Młodzieży PKiN powstał klub UKS Syrena (zastępujący klub MKS PM), obejmując grupę dzieci uzdolnionych w sekcji skoków do wody.

Wiek XXI przyniósł kolejne sukcesy wychowanków sekcji skoków do wody w PM PKiN: m.in.w latach 2003-2006 w Mistrzostwach Europy Juniorów (MEJ) i Mistrzostwach Europy Seniorów (MES) w 2006 r. W 2008, Kamil Gackowski zajął miejsca punktowane w czasie Mistrzostw Europy i w Pucharze Świata w skokach z wieży, w Mistrzostwach Europy Juniorów w Bergamo w 2014 r. Aleksander Gniadek zdobył II miejsce w skokach z wieży, w 2016 r. za- 
wodnik zdobył miejsce punktowane w czasie Igrzysk Europejskich w Baku, w 2016 r. w czasie MEJ w Rijeka, MŚ w Kazaniu zawodnicy zdobyli miejsca punktowane, w 2017 r. miejsca punktowane w czasie MEJ w Bergen, w 2018 (Helsinki) i 2019 (Kazań) w czasie MEJ - miejsca punktowane w skokach z wieży i trampoliny.

Te sukcesy są bez watpienia zasługa pasji zawodników, odpowiednich programów szkoleń i treningów oraz zaangażowania trenerów, którzy w latach 1955-2020 pracowali z zawodnikami w sekcji skoków do wody PM-PKiN, w różnych uwarunkowaniach organizacyjnych i klubowych. Wśród nich należy wymienić, w kolejności chronologicznej pracy w sekcji: Aleksandra Rękasa, Halinę Bartkowiak, Józefa Włodarczyka, Jerzego Niemińskiego, Wiktora Wierniuka, Jerzego Elsnera, Andrzeja Wierniuka, Jerzego Sucheckiego, Andrzeja Nagiela, Jolantę Dębska, Reginę Krajanow-Synoradzka, Elżbietę Sowińska, Elżbietę WierniukJózwiak, Krzysztofa Bojarskiego, Romana Godzińskiego, Tadeusza Budka, Annę Wierniuk, Bartłomieja Krynickiego i Velentina Suchanowa [skokidowody.waw.pl 2021] (tabela 4).

Tabela 4. Zajęcia organizowane na pływalni w Pałacu Młodzieży w Warszawie: skoki do wody (grupy, wiek, wymagania uczestnictwa, efekty)

\begin{tabular}{|c|c|c|c|}
\hline Rodzaj zajęć & $\begin{array}{l}\text { Wiek } \\
\text { (lat) } \\
\end{array}$ & $\begin{array}{c}\text { Wymagania / kryteria } \\
\text { kwalifikacji uczestnictwa }\end{array}$ & Program zajęć, spodziewane efekty \\
\hline $\begin{array}{l}\text { Grupy } \\
\text { początkowe } \\
(12 \text { osób), F/M }\end{array}$ & $6-15$ & $\begin{array}{l}\text { Dobra umiejętność } \\
\text { pływania: przepłynięcie } \\
25 \text { m dowolnym stylem } \\
\text { Gibkość, siła, skoczność } \\
\text { (ćwiczenia na lądzie) } \\
\text { Skok do wody: ze słupka } \\
\text { przodem na nogi lub } \\
\text { głowę, skok na nogi } \\
\text { z wysokości } 3 \mathrm{~m}\end{array}$ & $\begin{array}{l}\text { Doskonalenie pływania stylami } \\
\text { kraulem, grzbietowym, klasycz- } \\
\text { nym, nauka skoku startowego i na- } \\
\text { wrotów w poszczególnych stylach, } \\
\text { nauka skoków z przodu i z tyłu } \\
\text { z trampoliny (1 m i } 3 \mathrm{~m} \text { ), nauka } \\
\text { skoków z wieży } 5 \mathrm{~m} \text {, gimnastyka } \\
\text { ogólnorozwojowa, rozwój spraw- } \\
\text { ności fizycznej, wiedza na temat } \\
\text { bezpiecznych zachowań nad woda, } \\
\text { udział w zawodach i imprezach, } \\
\text { udział w obozach letnich, zimowych } \\
\text { i zgrupowaniach. } \\
\text { Efekty: rozwinięcie pożądanych } \\
\text { cech motorycznych (zwinność, } \\
\text { szybkość, równowaga, gibkość, siła, } \\
\text { koordynacja). } \\
\text { Umocnienie pasji, zamiłowania do } \\
\text { uprawiania sportu, ukształtowa- } \\
\text { nie postawy etycznego zawodnika, } \\
\text { umiejętność samokontroli i samo- } \\
\text { oceny. }\end{array}$ \\
\hline
\end{tabular}




\begin{tabular}{|c|c|c|c|}
\hline Rodzaj zajęć & $\begin{array}{l}\text { Wiek } \\
\text { (lat) }\end{array}$ & $\begin{array}{l}\text { Wymagania / kryteria } \\
\text { kwalifikacji uczestnictwa }\end{array}$ & Program zajęć, spodziewane efekty \\
\hline $\begin{array}{l}\text { Grupy średnio- } \\
\text { zaawansowane } \\
\text { (12 osób), F/M }\end{array}$ & $6-18$ & $\begin{array}{l}\text { Dobra umiejętność } \\
\text { pływania: przepłynięcie } \\
50 \text { m dowolnym stylem } \\
\text { Gibkość, siła, skoczność } \\
\text { (ćwiczenia na lądzie) } \\
\text { Skok do wody: skok } \\
\text { z trampoliny na głowę } \\
\text { przodem z wysokości } \\
3 \text { m, skok na nogi przo- } \\
\text { dem z wieży } 5 \text { m, skok } \\
\text { na nogi z wysokości } \\
7,5 \text { m }\end{array}$ & $\begin{array}{l}\text { Doskonalenie pływania stylami } \\
\text { kraulem, grzbietowym, klasycz- } \\
\text { nym i motylkowym, nauka skoków } \\
\text { z przodu i z tyłu z trampoliny (1 m } \\
\text { i } 3 \mathrm{~m} \text { ), nauka skoków z wieży } 5 \mathrm{~m} \text {, } \\
7,5 \mathrm{~m}, 10 \mathrm{~m} \text {, gimnastyka ogólnoro- } \\
\text { zwojowa i specjalistyczna (elemen- } \\
\text { ty akrobatyki), rozwój sprawności } \\
\text { fizycznej (siła, skoczność, gibkość, } \\
\text { wytrzymałość), wiedza na temat } \\
\text { bezpiecznych zachowań nad woda, } \\
\text { udział w zawodach i imprezach, } \\
\text { udział w obozach letnich, zimowych } \\
\text { i zgrupowaniach. } \\
\text { Efekty: rozwinięcie pożądanych } \\
\text { cech motorycznych (zwinność, } \\
\text { szybkość, równowaga, gibkość, siła, } \\
\text { koordynacja). } \\
\text { Umocnienie pasji, zamiłowania do } \\
\text { uprawiania sportu, ukształtowa- } \\
\text { nie postawy etycznego zawodnika, } \\
\text { umiejętność samokontroli i samo- } \\
\text { oceny. }\end{array}$ \\
\hline
\end{tabular}




\begin{tabular}{|c|c|c|c|}
\hline Rodzaj zajęć & $\begin{array}{l}\text { Wiek } \\
\text { (lat) }\end{array}$ & $\begin{array}{c}\text { Wymagania / kryteria } \\
\text { kwalifikacji uczestnictwa }\end{array}$ & Program zajęć, spodziewane efekty \\
\hline $\begin{array}{l}\text { Grupy } \\
\text { zaawansowane/ } \\
\text { mistrzowskie } \\
\text { (12 osób), F/M }\end{array}$ & $6-18$ & $\begin{array}{l}\text { Pływanie: przepłynięcie } \\
50 \text { m dowolnym stylem } \\
\text { Skoczność, gibkość, siła, } \\
\text { koordynacja ruchowa - } \\
\text { ćwiczenia na lądzie } \\
\text { Skoki do wody (ocenie } \\
\text { podlega poprawność } \\
\text { techniczna ćwiczenia): } \\
\text { - } 4 \text { skoki z grup podsta- } \\
\text { wowych z trampoliny } \\
1 \text { m } \\
\text { - skok z wieży } 5 \text { m na } \\
\text { głowę } \\
\text { - skok z wieży } 7,5 \text { m na } \\
\text { nogi lub głowę }\end{array}$ & $\begin{array}{l}\text { Grupa mistrzowska, kontynuacja } \\
\text { treningów: umiejętności skoków } \\
\text { z trampoliny (4 grupy) oraz z wieży } \\
\text { ( } 3 \text { grupy), opanowanie nowych sko- } \\
\text { ków w zależności od wieku (tram- } \\
\text { polina, wieża). } \\
\text { Udział w imprezach i zawodach, po- } \\
\text { kazach Pałacu Młodzieży, zdobywa- } \\
\text { nie klas sportowych. } \\
\text { Efekty: rozwinięcie pożądanych } \\
\text { cech motorycznych (zwinność, } \\
\text { szybkość, równowaga, gibkość, siła, } \\
\text { koordynacja). } \\
\text { Umocnienie pasji, zamiłowania do } \\
\text { uprawiania sportu, ukształtowa- } \\
\text { nie postawy etycznego zawodnika, } \\
\text { umiejętność samokontroli i samo- } \\
\text { oceny. }\end{array}$ \\
\hline
\end{tabular}

Źródło: opracowanie autorów na podstawie materiałów udostępnionych przez Pałac Młodzieży (2021) Objaśnienie: F - dziewczęta, M - chłopcy

\section{Zakończenie i dyskusja}

Pałac Młodzieży w Warszawie został oddany do użytku w 1955 r., jako część gmachu Pałacu Kultury i Nauki, wzniesionego w stylu socrealizmu. Kryta pływalnia należała do ważnego segmentu funkcjonalnego obiektu 'Wychowanie fizyczne i sport'.

Pływalnia w Pałacu Młodzieży była wówczas, i jest nadal, jedyną pływalnią krytą w województwie mazowieckim, na której jest możliwe uprawianie skoków do wody w pełnym zakresie konkurencji tej dyscypliny (skoki z wieży 10-metrowej). Jest to jednocześnie jedna z kilku pływalni w Polsce, na której można uprawiać tę dyscyplinę w pełnym zakresie konkurencji przez cały rok (inne to np. Zatoka Sportu w Łodzi, Termy Maltańskie w Poznaniu, OSIR Rzeszów). Pozostałe, to kilkanaście obiektów, na których można uprawiać skoki do wody, ale w niepełnym zakresie konkurencji, wśród nich jest np. OSIR Częstochowa (brak wieży 10-metrowej).

Brak odpowiednich obiektów w naszym kraju jest wypadkową wielu przyczyn: z jednej strony niewystarczających środków na inwestycje sportowe, wysokich kosztów realiza- 
cji i utrzymania krytych pływalni oraz precyzyjnych i konsekwentnych wymagań federacyjnych FINA (Federation Internationale de Natation) dla uprawiania tej dyscypliny, które obiekt o takiej funkcji musi spełniać.

Trudno się natomiast zgodzić z argumentem, często przytaczanym m.in. w oficjalnych raportach, że ograniczenia środków na inwestycje pływalni z wieżą do pełnego zakresu skoków, są konsekwencją braku zainteresowania tą dyscypliną wśród dzieci i młodzieży. Obserwowane od dekad, rok roczne wielkie zainteresowanie rekrutacją na zajęcia w tej sekcji w Pałacu Młodzieży i osiągane znaczące sukcesy sportowe wychowanków - temu bardzo wyraźnie przeczą. Dzieje się tak pomimo wyjątkowych wymagań, jakie są stawiane sportowcom uprawiajacym skoki do wody - pracowitości i konsekwencji, odwagi i sprawności fizycznej, elegancji ruchów i precyzyjnego wykonywania ćwiczeń, natomiast z pewnością istotnym magnesem jest wyjątkowa widowiskowość tej dyscypliny.

Z kolei bez watpienia prawdziwym jest argument na temat wysokich kosztów budowy i utrzymania obiektu. Regulacje FINA dotyczące wymagań obiektu do treningu i organizacji skoków do wody znajdują się w opracowaniu FINA Rules and Regulation Handbook (sekcje 5.1-5.3), z $2017 \mathrm{r}$.

Zgodnie z zawartymi tam regulacjami, powierzchnia niecki basenu przeznaczonego do zajęć skoków do wody lub część basenu przeznaczona do tych zajęć, powinna wynosić: długość: 18,29 m, szerokość: 22,89 m. Basen powinien być wyposażony w dwie trampoliny na wysokości $1,0 \mathrm{~m}$, dwie trampoliny na wysokości 3,0 m oraz wieżę z poziomami skoków na wysokości $5 \mathrm{~m}, 7,5 \mathrm{~m}$ oraz $10 \mathrm{~m}$. Temperatura wody powinna mieć minimum $26^{0} \mathrm{C}$. Pod trampolinami umocowanymi na wysokości 1,0 m głębokość wody powinna wynosić minimum 3,4 m, pod trampolinami na wysokości 3,0 $\mathrm{m}$ - głębokość 3,7 m, pod wieżą na wysokości 5,0 m - głębokość 3,7 m, pod wieżą na wysokości 7,5 $\mathrm{m}$ - głębokość 4,1 m, pod wieżą na wysokości $10 \mathrm{~m}-4,5 \mathrm{~m}$.

Ponadto wymagania federacji FINA w stosunku do obiektu, na którym mają miejsce treningi i zawody w skokach do wody, obejmują tak szczegółowe regulacje jak: precyzyjne cechy (materiał, konstrukcja) i wymiary trampolin, wieży do skoków, ich lokalizację, odległości do ścian i sufitu, otoczenia niecki basenu i urządzeń tam się znajdujących [www. fina.org].

W 2007 r. wpisano Pałac Kultury i Nauki wraz z otoczeniem (Plac Defilad) do rejestru zabytków. Niezbędne dla dalszego funkcjonowania obiektu prace modernizacyjne, które miały miejsce na pływalni PM-PKiN w latach 2013-2016, musiały uwzględnić bardzo restrykcyjne i szczegółowe rekomendacje programu konserwatorskiego, narzucającego zachowanie historycznych walorów stylu architektonicznego pływalni.

Oddana w 2016 r. do użytku po zabiegach renowacyjnych pływalnia w PM-PKiN służy obecnie sekcji pływackiej, w tym zajęciom i treningom skoków do wody oraz zajęciom rekreacyjnym. Wielofunkcyjność pływalni, jej różnorodne wykorzystanie - szkolenia, treningi sportowe, zajęcia rekreacyjne, zawody i pokazy - umożliwiają równoważenie budżetu i utrzymanie kosztownego i wymagającego w eksploatacji obiektu.

Historia sekcji skoków do wody w PM-PKiN Warszawa, jednej z pierwszych, najdłużej działających i nadal nielicznych w Polsce, dobrze ilustruje, jak niezwykle konsekwentnie 
realizowany, nieprzerwanie od 65 lat, pomimo zmieniających się uwarunkowań zewnętrznych, program szkoleń i treningów może mieć decydujący wpływ na znaczące sukcesy sportowe wychowanków.

Bez watpienia 65-letnia historia pływalni w Pałacu Młodzieży w Warszawie jest przykładem, jak ważne jest zachowanie tradycji, ciagłości działalności sportowej i wychowawczej, jak potrzebne jest szukanie udanych kompromisów dla - z jednej strony - niezbędnych zabiegów modernizacji i dostosowania obiektu sportowego do współczesnych wymagań, z drugiej strony - ochrony jego historycznego stylu i substancji zabytkowej, bez uszczerbku dla funkcji i współczesnych wartości użytkowych. Dzięki temu zachowana jest tradycja miejsca, dokument historii ważny dla krajobrazu miasta i jego mieszkańców.

\section{Literatura}

Bogusz A., 1975, Budowa PKiN, Panstwowe Wydawnictwo Naukowe, Warszawa.

Crowley D., 1997, People's Warsaw, Journal of Design History, 10, 2, s. 203-223; DOI: doi. org/10.1093/jdh/10.2.203.

Dorrian M., 2010, Falling upon Warsaw: the shadow of the Palace of Culture, The Journal of Architecture, 15, 1, s. 87-103; DOI: doi.org/10.1080/1360236090357619.

Drozdowski M., Sołtan M., Zahorski A., 2017, Historia Warszawy, Wydawnictwo Bellona, Warszawa.

Huml I., 2005, Pałac w guście epoki, Renowacje i Zabytki, 3, 15, s. 106-117.

Perkins P.H., 2000, Swimming Pools: Design and Construction, CRC Press (Architecture), NY.

Sigalin J., 1986, Warszawa 1944-1980. Z archiwum architekta, Państwowy Instytut Wydawniczy, Warszawa.

„Sportowiec", nr 18 z kwietnia 1955, artykuł: Otwarcie nowej pływalni w Pałacu Młodzieży $w$ Warszawie (autor nieznany, podpisany inicjałami).

Wertz S.K., 1985, Sport and the Artistic, Philosophy Journal, 60, 233, Cambridge University Press, s. 392-393; DOI: 10.1017 / S0031819100070236.

Wojtysiak M., 2005, Remonty i modernizacje w Pałacu Kultury i Nauki-zabytku epoki socrealizmu, Renowacje i Zabytki, 3, 15, s. 162-167.

Zieliński J., 2012, Pałac Kultury i Nauki, Księży Młyn, Łódź. 


\section{Strony internetowe}

www.fina.org [dostęp: 2021]

www.nowawarszawa.pl. [dostęp: 2021]

www. PKiN.pl [dostęp: 2021]

www.pm.waw.pl [dostęp: 2021]

www.skokidowodywaw.pl [dostęp: 2021]

www.skyscraperpage [dostęp: 2021]

\section{5-year jubilee of swimming pool in the Palace of Youth in Warsaw}

\section{ABSTRACT}

The Palace of Youth in Warsaw was opened 65 years ago, in April 1955, as a part of the Palace of Culture and Science building (PKiN), erected in the style of socialist realism. At that time, it was an extraordinary attraction, offering children unattainable elsewhere opportunities to develop their passions and interests. For example, the indoor swimming pool at the Palace of Youth was (and still is) the only swimming pool in the Masovian Voivodeship where diving is possible. At the same time, it is one of the few swimming pools in Poland where this discipline can be practiced in the full range of competition throughout the year. In 2007, the Palace of Culture and Science and its surroundings (Parade Square) entered into the register of historic monuments. The modernization works that took place in the Palace of Youth, including PM-PKiN swimming pool, had to take into account very restrictive and detailed recommendations of the conservation program, which imposed preservation of the historical values of architectural style of the swimming pool.

The swimming pool at PM-PKiN, which was reopened in 2016 after renovation, is now used by the swimming section (activities: water polo, diving, swimming, aerobics).

Key words: history of architecture, history of sport, PKiN Warsaw, swimming pool 


\section{JUBILEUSZ 65 LAT DZIAŁALNOŚCI PŁYWALNI W PAŁACU MŁODZIEŻY W WARSZAWIE}

Bartłomiej Krynicki, Anna Pawlikowska-Piechotka

Bartłomiej Krynicki, dr - ur. 1973 r. w Warszawie, absolwent studiów magisterskich i podyplomowych Akademii Wychowania Fizycznego w Warszawie oraz Uniwersytetu Karola Stefana Wyszyńskiego w Warszawie. Dyrektor Pałacu Młodzieży w Warszawie, nauczyciel akademicki oraz trener skoków do wody, instruktor narciarstwa, snowboardu, żeglarstwa, kajakarstwa, windsurfingu, rekreacji, fitness, survival. Jest międzynarodowym sędziq̨ skoków do wody, posiada Europejski Certyfikat Trenerski LENa w skokach do wody. Jest obecnie Trenerem Kadry Narodowej w skokach do wody Polskiego Zwiqzku Pływackiego, jego podopieczni zdobywali zaszczytne miejsca w tej dyscyplinie, w tym na Mistrzostwach Europy Juniorów (wicemistrzowski medal). Brał udział w wielu pracach badawczych, był organizatorem i uczestnikiem międzynarodowych konferencji naukowych i branżowych. Jest autorem oraz współautorem kilkudziesięciu opracowań twórczych: autorskich programów trenerskich oraz publikacji naukowych (artykułów naukowych i popularno-naukowych, monografii, podręczników i skryptów), które ukazały się w językach polskim, rosyjskim i angielskim. Kontakt: Akademia Wychowania Fizycznego Józefa Piłsudskiego w Warszawie; ORCID: 0000-0003-2109-5216;

e-mail: bartlomiej.krynicki@awf.edu.pl

Bartłomiej Jan Krynicki, PhD - born 1973 in Warsaw, graduate and postgraduate of the Józef Piłsudski University of Physical Education in Warsaw and Cardinal Stefan Wyszyński University in Warsaw. Director of the Palace of Youth in Warsaw, academic teacher and diving coach, instructor of skiing, snowboarding, sailing, canoeing, windsurfing, recreation, fitness, survival. An international judge of diving and holds the European LENA Coaching Certificate in diving. Currently - the Coach of the National Team in diving of the Polish Swimming Federation, his protégés won honourable places in this discipline, including the European Junior Championships (vice-championship medal). He participated in many research works, organized and attended international scientific and industry conferences. Author and co-author of several dozen creative studies: original training programs and scientific publications (scientific and popular science articles, monographs, textbooks and scripts), which were published in Polish, Russian and English.

Contact: Józef Piłsudski University of Physical Education in Warsaw, Faculty of Physical Education; ORCID: 0000-0003-2109-5216; e-mail: bartlomiej.krynicki@awf.edu.pl

Anna Pawlikowska-Piechotka, prof. dr hab. inż. arch. - architekt i urbanista, w latach 2004-2014 profesor wizytujący na University College Birmingham (Wielka Brytania), Charles University of Prague (Czechy), University of Lahti (Finlandia), University of Saragossa (Hiszpania), University of Evora (Portugalia), University of Viseau (Portugalia), Holar University (Islandia). W swoich badaniach koncentruje się na wykorzystaniu dziedzictwa kulturowego dla zrównoważonego rozwoju turystyki i odpowiedzialnego planowania przestrzeni turystyki, sportu i rekreacji. Uczestniczyła w kilku międzynarodowych projektach badawczych (Niemcy, Szwecja, Holandia, Wielka Brytania, Polska, Turcja); jest autorem ponad dwustu publikacji naukowych, w tym kilku monografii, tekstów opublikowanych w języku angielskim, niemieckim, polskim i serbskim; współautor kilkudziesięciu planów architektonicznych i urbanistycznych (zrealizowanych w Polsce, Niemczech, Nigerii i Libii) oraz wzorów użytkowych obiektów rekreacyjnych dla osób niepełnosprawnych - formalnie zarejestrowanych w Urzędzie Patentowym RP.

Kontakt: Akademia Wychowania Fizycznego Józefa Piłsudskiego w Warszawie; ORCID: 0000000304290327 ;

e-mail:anna.piechotka@gmail.com

Anna Pawlikowska-Piechotka, Professor - architect and urban planner, between 2004-2014 a visiting professor at University College Birmingham (United Kingdom), Charles University of Prague (Czech Republic), University of Lahti (Finland), University of Saragossa (Spain), University of Evora (Portugal), University of Viseu (Portugal), Holar University (Iceland). Focuses in her research on the usage of cultural heritage for sustainable tourism and responsible planning for tourism, sport and recreation. Participated in several international research projects (Germany, Sweden, Holland, UK, Poland, Turkey). Author of over two hundred scientific publications, including several monographs, papers published in English, German, Polish and Serbian. Co-author of several architectural and urban plans of recreation and tourist space (commissioned in Poland, Germany, Nigeria and Libya) and utility models of recreation facilities for disabled - formally registered in the Polish Patent Office.

Contact: Józef Piłsudski University of Physical Education in Warsaw; ORCID: 0000000304290327 ;

e-mail:anna.piechotka@gmail.com 